Pamiętnik Literacki 2020, 2, s. 167-174

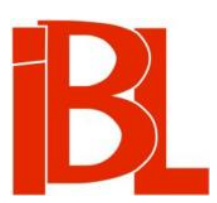

Dwór Boga (i Archaniol Gabriel) w "Pośle niebieskim" Andrzeja Dębołęckiego oraz w "Poważnej legacyi" Aleksandra

Obodzińskiego

Dariusz Dybek 


\section{DWÓR BOGA (I ARCHANIOŁ GABRIEL) W „POŚLE NIEBIESKIM” ANDRZEJA DEBBOEECKIEGO ORAZ W „POWAŻNEJ LEGACYI” ALEKSANDRA OBODZIŃSKIEGO}

W Bibliografii polskiej Karola Estreichera znalazło się dwóch Dębołęckich (Dembołęckich): Andrzej oraz Wojciech ${ }^{1}$. Ten drugi jest powszechnie znany (i osławiony) przede wszystkim jako autor Wywodu jedynowłasnego państwa świata. Andrzej Dębołęcki nie spotkał się dotąd $z$ tak wielkim zainteresowaniem historyków literatury staropolskiej. Wprawdzie spod jego pióra wyszło sporo dzieł, głównie podejmujących tematykę religijną lub polityczną (albo łączących obie te sfery), lecz nie okazały się one atrakcyjne dla badaczy kultury szlacheckiej ${ }^{2}$. Do zestawu utworów pisarza $z$ Konojad wymienionego przez wybitnego bibliografa dodano niedawno jeszcze Posła niebieskiego, to jest Archanioła Gabryjela nowinę z nieba do Panny czystej Maryjej o wcieleniu Syna Bożego w jej żywot sprawujacego ${ }^{3}$ - druk ten odnalazł i wspomniał w swym opracowaniu Maciej Eder ${ }^{4}$. Dostrzeżono w owym poemaciku nawiązania do jednego $z$ ważnych dzieł przedstawiających Zwiastowanie Marii Pannie przez Gabriela, czyli do epopei De partu Virginis Jacopa Sannazara ${ }^{5}$.

Czytając już prolog utworu wydanego w 1633 r. w Toruniu, pozbawieni zostajemy nadziei na obcowanie $z$ wybitną literaturą. Dębołęcki zaczyna od wyznania, że dawno już „nie śpiewał z Muzami”, wyruszył więc na poszukiwanie patronek artystów. W ustroniu natknął się na Erato: ta wprawdzie obiecała poecie sprowadzić swe siostry, lecz nagle zniknęła. I wówczas wydarzyło się coś niezwykłego:

\footnotetext{
W tym swe oczy obrocę ku niebu jasnemu,

Zadumawszy się wielce pomieszaniu temu,

A oto złoty obłok stanął otoczony

Wkoło jakby purpura, ten na wszytkie strony
}

1 K. Estre i c he r, Bibliografia polska. Cz. 3, t. 4. Kraków 1897, s. 90-92.

2 Do wyjątków należy J. Kro c zak („Jeśli mię wiedźba prawdziwa uwodzi...” Prognostyki i znaki cudowne $w$ polskiej literaturze barokowej. Wrocław 2006, s. 50-60), który w swej monografii poświęconej prognostykom w polskiej literaturze XVII w. poświęcił sporo miejsca jednemu z dziełek A. Dębołęckiego, czyli Wróżbitowi boju moskiewskiego.

3 A. D ę b oł ę c k i, Poseł niebieski, to jest Archanioł Gabryjel nowinę z nieba do Panny czystej Maryjej o wcieleniu Syna Bożego w jej żywot sprawujacy. Toruń 1633.

4 Polonica ze zbiorów Zamku Skokloster. Katalog. Oprac. M. E d e r, przy współpr. E. W e s tin B e r g. Red. nauk. D. Chem perek. Warszawa 2008, poz. 35.

5 Zob. R. M z zu rki e w i c z, O staropolskich przekładach „De partu Virginis” Sannazara. W: Z dawnej literatury maryjnej. Zarysy i zbliżenia. Kraków 2011, s. 198. 
Złotonitne promienie $\mathrm{z}$ blaskiem wypuszczając,

Trząsł się z światła wielkiego, w pewnej mierze trwając.

W tym złoty było widać Majestat, gdzie siedział

Bóg najwyższy, który to już przed wieki wiedział,

Co się z światem dziać miało, a pobok stolice

Świetnych orszaków gęste stanęły ulice,

Z których śrzodku przedziwne pienie wynikało,

Które wszytkie niebiosa wdzięcznie napełniało.

Gmin wielki w koło stoi prożnych śmiertelności

Duchów, usługujących Bożej wszechmocności.

Każda $z$ nich hierarchi[j]a, każdy poczet swemu

Cześć wyrządza inakszą Bogu najwyższemu.

Stoją uszykowani jako więc do boju6 ${ }^{6}$.

Dębołęcki to nie pierwszy twórca, którego zainteresował temat dworu niebiańskiego. Sięgnięcie po niego jest usprawiedliwione sugestią zawartą w tytule dzieła Gabriel ma przekazać Maryi decyzje podjęta w niebie ${ }^{7}$. Autor Posła niebieskiego zrezygnował wszakże $\mathrm{z}$ precyzji w przedstawieniu narad sejmu niebiańskiego. $\mathrm{W}$ piśmiennictwie staropolskim znajdujemy niemało realizacji owego motywu. Jedną z nich zawarł w swej Lutni wdzięcznobrzmiacej na uroczyste Bogarodzice Panny święta $w$ panegirycznych [...] kazaniach wyciagnionej późnobarokowy duchowny Andrzej Karp. W kazaniu zatytułowanym Konsulta Trójce Przenaświętszej o wcieleniu Syna Bożego streścił on przebieg swoistego posiedzenia Trójcy i konkludował:

Już stanęła, katolicy moi, w konsystorzu Trójce Przenaświętszej konsulta, padły zgodliwe wszytkich trzech Osób na Syna Bożego vota, aby ludzką w żywocie panieńskim przyjąwszy naturę, onęż krzyżową śmiercią i innemi okrutnemi mękami de condigno odkupił ${ }^{8}$.

Znacznie dokładniej, ale już w postaci wierszowanej, obrady niebiańskie przedstawił Szymon Gawłowicki w mesjadzie Jezus Nazareński, Syn Ojca Przedwiecznego wcielony albo Jeruzalem niebieska przezeń wyzwolona. Wydane w $1686 \mathrm{r}$. dzieło, w którym połączono biblijno-apokryficzną tematykę $\mathrm{z}$ formą zaczerpniętą z Gofreda abo Jerozolimy wyzwolonej Torquata Tassa w tłumaczeniu Piotra Kochanowskiego, zawiera relację $z$ dialogu Ojca, Syna i Ducha, stanowiących senat niebieski. „Konsulta” przypomina naradę możnowładców dyskutujących o przyszłości państwa. Przemowę Syna Bożego Gawłowicki wprowadza słowami:

\author{
Jako więc król aboli też który \\ Potentat wielkiej władze i możności, \\ Siedząc na tronie między radnych zbory \\ Nie przez kanclerskie usta o całości \\ Państwa swojego (jako wielkie dwory \\ Czynia), lecz mimo zwyczaj dostojności, \\ Gdy przez się rzecz ma, mucha nie zabeczy,
}

6 Dębołę cki, op. cit., k. $\mathrm{B}_{3}-\mathrm{B}_{3} \mathrm{r}$.

7 Zob. J. J. Ko p éc, Bogarodzica w kulturze polskiej XVI wieku. Lublin 1997, s. 81.

8 A. Ka r p, Konsulta Trójce Przenaświętszej o wcieleniu Syna Bożego. W: Lutnia wdzięcznobrzmiaca na uroczyste Bogarodzice Panny święta $w$ panegirycznych [...] kazaniach wyciagniona. Kraków 1695, s. 269. 
Weń wzrok trzymając jako w jasnej tęczy. Równie na słowo Przedwiecznej Mądrości, Umilkną wszyscy $[. . .]^{9}$.

Oba zacytowane dzieła pojawiły się już po napisaniu Posła niebieskiego. Nie oznacza to, że Dębołęcki nie miał wzorców, na których mógłby się oprzeć, dokładnie ukazując, jak Trójca Święta ustalała, co trzeba zrobić, by wyrwać człowieka spod władzy szatana (właśnie taki był cel Boga ${ }^{10}$ ). Do najistotniejszych źródeł w tym zakresie należały rozważania św. Bernarda z Clairvaux. W kazaniu Na Zwiastowanie Najświętszej Maryi Panny opisał on obrady, w których wzięli udział Bóg oraz aniołowie: „W pośrodku [...] zasiadał Ojciec Światłości i mówił, co miał najlepszego, na korzyść każdej ze stron" ${ }^{11}$. Słynny cysters zainspirował wielu teologów i twórców podejmujących temat miłosierdzia Bożego, które objawiło się w tym, że - za pośrednictwem Maryi - ludziom dany został Jezus ${ }^{12}$.

Andrzej Dębołęcki jednak, jak już zauważono, poskapił czytelnikom informacji, w jaki sposób przebiegały narady w niebie. W zamian opisał niebiosa, w których miejscem centralnym jest tron Stwórcy. W początkowych wersach zacytowanej wizji dworu niebieskiego podkreślona została niezwykłość tego miejsca. Objawieniu towarzyszy przecież zjawisko niecodzienne: złoty obłok, który „Trząsł się z światła wielkiego [...]”. Owa deskrypcja przypomina treść wielu dzieł plastycznych, na których Majestat Boży można zobaczyć w obłoku chwały. Podobnie tradycyjny jest obraz armii anielskiej zgromadzonej wokół Najwyższego:

Dwór Stwórcy pojawia się zwłaszcza w tych dziełach, które umieszczają fabułę w zaświatach, a przede wszystkim (co oczywiste) w niebie. „W tego rodzaju relacjach aniołowie pojawiają się nader często, jednak teksty te, co może wydawać się nieco dziwne, tylko w stosunkowo niewielkim stopniu nawiązują do współczesnej sobie [tj. do średniowiecznej] refleksji angelologicznej [...], za to systematycznie odsyłają do dawnych tradycyjnych wyobrażeń zaczerpniętych z Biblii, apokryfów, a niekiedy również z dzieł pogańskich autorów greckich i rzymskich, czy wreszcie do ludowych wierzeń" ${ }^{3}$.

Do motywów wywodzących się z Pisma Świętego, a zwłaszcza ze Starego Testamentu, należy m.in. obraz Boga zasiadającego na tronie i otoczonego przez anioły. Pojawia się on w Księdze Izajasza, w wizjach Daniela, w psalmach czy w I Księdze Królewskiej ${ }^{14}$.

W wieku XVII stereotypowe wyobrażenia na temat wyglądu nieba zawierały więc

Sz. G a wł o w i c ki, Jezus Nazareński, Syn Ojca Przedwiecznego wcielony albo Jeruzalem niebieska przezeń wyzwolona. Warszawa 1686, s. 86.

Zob. L. Te u s z, Bolesna Muza nie Parnasu góry, ale Golgoty... Mesjady polskie XVII stulecia. Warszawa 2002, s. 78.

Bernard z Cla irva ux, Na Zwiastowanie Najświętszej Maryi Panny. W: Kazania o najświętszej Maryi Pannie, poprzedzone encyklika Ojca Świętego Piusa XII „Doctor Mellifluus” o św. Bernardzie z Clairvaux w osiemsetna rocznicę Jego śmierci. Przeł. I. B o b i c z. Warszawa 2000, s. 106.

Zob. P. S tę p i eń, Chaos i ład. „Lament świętokrzyski”. W: Z literatury religïnej polskiego średniowiecza. Studia o czterech tekstach: „Kazanie na dzień św. Katarzyny”, „Legenda o św. Aleksym”, „Lament świętokrzyski”, „Żottarz Jezusow”. Warszawa 2003, s. 241-242.

Cyt. za: J. S o kols k i, Dwór niebieski, strażnicy bram i posłańcy Boga. W zb.: Anioł $w$ literaturze $i w$ kulturze. T. 1. Red. J. Ług ow ska, J. Skawiński. Wrocław 2004, s. 59.

D. Dybek, Anioł w piśmiennictwie polskim XVII i XVIII wieku. Wrocław 2012, s. 215. Zob. też F. M. Ro siń s ki, Koncepcja aniołów $w$ „Starym Testamencie”. W zb.: Anioł $w$ literaturze i $w$ kulturze, s. 16. 
wiele powtarzających się elementów, co wynikało $\mathrm{z}$ sięgania do podobnych źródeł. Otoczony strażnikami Bóg, który zasiada na tronie - to jeden $z$ głównych motywów. Spotykamy się też ze swoistym „udomowieniem” wizji zaświatów, polegającym na nadaniu niebu cech typowych dla dworów, w których autorzy deskrypcji mogli bywać. W wyobrażeniach ówcześnie żyjących ludzi dwór niebieski niewiele różnił się od magnackiego czy królewskiego: tu i tam względy monarchy wyjednywało się poprzez jego najbliższe otoczenie, najwierniejsze sługi, obdarzone łaską i zaufaniem panujacego ${ }^{15}$.

Autor Posła niebieskiego w nierozbudowanym opisie uwypuklił kilka kwestii związanych z czcią, jaką niebiańskie duchy otaczają Stwórcę. Aniołowie tu śpiewają i jest to cecha wspólna wszystkich bytów niebieskich. Równocześnie każdy z chórów należących do hierarchii "Cześć wyrządza inakszą Bogu najwyższemu”. W ten sposób Dębołęcki odwołuje się (niekoniecznie bezpośrednio) do ustaleń największego autorytetu w dziedzinie angelologicznej, czyli do Pseudo-Dionizego i jego Hierarchii niebiańskiej. Areopagita podzielił anioły na trzy triady, z których każda składa się z trzech chórów. Ów podział wynikał zaś ze specyfiki zadań poszczególnych grup duchów niebieskich - owe chóry wyglądają odmiennie, w różny sposób są usytuowane na drabinie bytów i w innym celu zostały stworzone. Dębołęcki wprawdzie nie rozwija tego wątku, ale dyskretnie sygnalizuje ład w strukturze społeczności przebywającej w niebie.

Autor relacji spośród tłumu aniołów uhonorował zwłaszcza jednego - oczywiście: Archanioła Gabriela. Przecież już w tytule wymieniono imię najważniejszego z posłów. Co ciekawe, pierwsze przedstawiające go wersy koncentrują się na mniej oczywistej funkcji Gabriela:

\footnotetext{
Hetman męże stanowi, sam zasię w zawoju Głowę mając, wszytkiemu wojsku rozkazuje, Które go mile słucha i jemu hołduje. Hetman wojska tamtego, Gabryjel nazwany, Był w ten czas, a od Boga stanie zawołany. Pokłon odda przystojny, skłoniwszy kolana, Mowy czeka ochotnie od swojego Pana ${ }^{16}$.
}

Polski twórca nie od razu zatem zaprezentował Gabriela w roli, z którą ten anioł jest głównie kojarzony, tzn. legata przynoszacego wiadomość ${ }^{17}$. Najpierw ukazał go jako przywódcę anielskiej armii. Taką funkcję przeważnie przyznawano Archaniołowi Michałowi. Jednak w wielu tekstach apokryficznych obaj najwyżsi dostojnicy anielscy albo blisko współpracują, albo zgoła wyręczają się nawzajem w swych zadaniach.

Wynikało to $\mathrm{z}$ tego, że obu określano jako aniołów szczególnie walecznych i każdemu z nich przyznawano rolę wodza armii niebiańskich duchów. Mimo że Michał ostatecznie został przez tradycję uznany za przywódcę Bożych wojsk, to z dziejów polskiej kontrreformacji. Warszawa 1987, s. 224.

16 Dębołęcki, op. cit., k. $B_{3}$ r.

17 Zob. J. Daniélou, Aniołowie i ich misja. Przeł. K. Kub a s zc zy k. Warszawa 2006, s. 50-51. 
przecież pewien brak konsekwencji tu również można dostrzec. Dlatego Maciej Ignacy Tłuczyński napisał:

On [tj. Michał], jako mówi Pantaleon, wielki jest wódz wojska Pańskiego wespół z Gabrielem, błogosławiący, umacniający, łaską napełniający, uweselający i zdobiący wierne Boże [... $]^{18}$.

Z wojskową specjalizacją łączyć należy także fakt, że obu aniołów wybierano często na patronów sanktuariów znajdujących się w miejscach odludnych i traktowanych jako twierdze: „Cała Europa kojarzyła dowódców anielskich zastępów Z niedostępnymi miejscami, gdzie budowano poświęcone im sanktuaria” ${ }^{19}$. Nie przypadkiem zatem po duszę Rolanda w starofrancuskim eposie przyszli Cherubin oraz Michał z Gabrielem. Ci ostatni bywali obarczani zadaniami, jakie wypełniał psychopompos, ale ponadto - do nieba mieli zaprowadzić rycerza (czyli kogoś do pewnego stopnia im podobnego) ${ }^{20}$.

Wydaje się jednak, że autor Posła niebieskiego uświadamiał sobie, iż tradycyjnie Gabriela kojarzono nie tyle $z$ wojną, ile $z$ posłowaniem (zresztą, w dalszej części utworu właśnie na tym się Dębołęcki skoncentruje), i dlatego od razu podkreślił, że „Hetman wojska tamtego” to nie Michał!

Korzącemu się przed Bogiem archaniołowi Stwórca rozkazuje zanieść Maryi wiadomość o tym, że będzie Matką Syna Bożego. W tych słowach nie pojawiła się sugestia oczekiwania na zgodę dziewczyny z Nazaretu - Bóg oznajmia Swą wolę, łagodzac jej nie znoszący sprzeciwu charakter zaleceniem:

Pozdrów ją mile, [...]

Już niech pełna radości będzie i wesela ${ }^{21}$.

Odmienność zadań przydzielanych Gabrielowi i Michałowi nie zostaje uwypuklona przez Dębołęckiego. Zrobił to natomiast twórca, ktoś, kto kilka lat po nim opisał te same wydarzenia i po prostu splagiatował Posła niebieskiego. Chodzi o Aleksandra Obodzińskiego, autora (choć bardziej właściwe byłoby określenie kompilatora) Poważnej legacyi w Konsystorzu Trójce Przenaświętszej [... ${ }^{22}$. Wśród nielicznych nie skopiowanych od Dębołęckiego fragmentów ${ }^{23}$ znalazł się ten, który wyjaśnia, dlaczego to Gabriel został wybrany do delikatnej misji. Przedstawiajacc anioła, który w Biblii przede wszystkim przynosi bardzo ważne wiadomości, Obodziński zastosował technikę negacji:

Nie on to jest Cherubin, co miecze ogniste

Przy podwojach ma rajskich, gdzie wrota zamczyste,

M. I. Tł u c zy ń s k i, Anielska dobroczynność, którą święci Aniołowie z woli Boskiej całemu światu $z$ wielka miłościa wyrzadzaja [...]. Kraków 1677, s. 369.

A. Olę d zk a - Frybe s ow a, Patrzac na ikony. Wędrówki po Europie. Warszawa 2001, s. 188.

Zob. Dybek, op. cit., s. 66-67.

Dęboł ęcki, op. cit., k. $\mathrm{B}_{3} \mathrm{r}$.

A. O b o d zi ń s ki, Poważna legacyja w Konsystorzu Trójce Przenaświętszej, na uzdrowienie wszytkiego świata uradzonej, a przez Najwyższego Hetmana Hierarchij Niebieskich Anioła Gabriela $w$ domku Przenaświętszej Panny Maryjej, przed Wcieleniem Syna Bożego odprawiona. Kraków [1640?]. Obodziński przejął (niekiedy z bardzo niewielkimi zmianami) aż 380 wersów spośród 484, które składają się na Posła niebieskiego. 
Nie ten to, co w Egipcie okrutnie zabija, Ostrym żelazem dziatek pirwiastek nie mija, Ani ten, co śród wojska Senacheryb złego Trupy na pował kładzie, przebija każdego Ani ów, co Sodomę i Gomorę pali, Nie ten, co przed Dawidem miecz ognisty stali; Ten to jest, co postrachu przy sobie nie nosi, Ten to, co pokój ludziom wieczysty przynosi. Poseł to jest niebieski, poseł obiecany $Z$ konsystorzu Boskiego na ziemię zesłany ${ }^{24}$.

Porzucenie kontekstu militarnego stanowi przejaw pewnego rodzaju niekonsekwencji w obrazowaniu anioła, co przecież nie oznacza, że pierwotne przedstawienie Gabriela jako hetmana anielskiej armii było błędem ${ }^{25}$. Różnorodne źródła zawierały informacje o Gabrielu uczestniczącym w działaniach wojennych:

Według legendy żydowskiej Gabriel był aniołem, który z rozkazu Boga zniszczył grzeszne miasta (między innymi Sodomę i Gomorę). Według Talmudu [...] rozgromił wojska Sennacheryba „za pomocą naostrzonej kosy, przygotowanej w dniu Stworzenia”. [...] Gabriel bywa również identyfikowany jako anioł, który walczył z Jakubem w Penuel [...]. Według tradycji żydowskiej, w erze mesjańskiej Gabriel stoczy wielką bitwę $z$ Lewiatanem [...]. Zgodnie z sądowymi zeznaniami Joanny d'Arc, to Gabriel natchną ją, aby wyruszyła z odsieczą królowi Francji ${ }^{26}$.

Autor Poważnej legacyi w dalszej partii poematu skoncentrował się wszakże na koncyliacyjnym usposobieniu anioła (podobnie przedstawiony jest też Gabriel w Pośle niebieskim), którego na poziomie religijności ludowej postrzegano inaczej niż wodza wojsk niebiańskich, czyli Michała (to właśnie z nim szczególnie często łączono udział nie tylko w batalii, która rozgorzała tuż po buncie Lucyfera, ale również w bitwach rozgrywających się na ziemi - Michał miał wspomagać chrześcijan w niejednej potyczce $\mathrm{z}$ poganami ${ }^{27}$ ). Wizerunek Gabriela został więc w ciagu wieków pozbawiony atrybutów groźnego wojownika. Ten kierunek przemian odnosił się zresztą do wszystkich aniołów, którzy w Biblii oraz żydowskich i wczesnochrześcijańskich apokryfach często pełnili funkcje „biczów Bożych”, wymierzając kare przeciwnikom Stwórcy i narodu wybranego, natomiast sukcesywnie „przekazywali" te zadania diabłom ${ }^{28}$. Właśnie na przykładzie Gabriela można dostrzec stopniowe przeobrażenie charakteru ducha niebiańskiego. Wydaje się, że wcześniejsze ukazanie go jako wodza armii niebiańskiej miało przede wszystkim podkreślić wysoką pozycję $\mathrm{w}$ hierarchii bytów, a tym samym uzasadnić desygnowanie Gabriela na legata Boskiego ${ }^{29}$. Hetmańska godność nie była wszakże jedynym

Obodzińs ki, op. cit., k. $\mathrm{B}_{2} \mathrm{r}-\mathrm{B}_{2} \mathrm{v}$.

Podobne zestawienie znaleźć można też u Sannazara (zob. G. C z a r a dzki, Rytmy o porodzeniu przenaczystszym Bogarodzice Panny Maryjej. Wyd. R. Mazu rki ew icz, E. B u s zew i cz. Red. A. N ow i ck a - J e ż ow a. Warszawa 2009, s. 58).

G. Davidso n, Słownik aniołów, w tym aniołów upadłych. Przeł. J. Ruszkowski. Poznań 2003, s. 125-127.

Zob. K. M o is a n-J a bł oń s ka, Michał Archanioł zwyciężający szatana. W: Obrazowanie walki dobra ze złem. Kraków 2002.

Zob. W. B r oj e r, Diabeł w wyobraźni średniowiecznej. Trzynastowieczne exempla kaznodziejskie. Wrocław 2003, s. 328.

Nazywanie Gabriela posłem usprawiedliwione było i etymologia słowa „anioł”, i waga powierzonej 
powodem wybrania go, empatia (a tej można spodziewać się po aniele, który: nie wzbraniał ludziom wstępu do raju, nie zabił pierworodnych Egipcjan, nie zniszczył Sodomy itd.) to bowiem cecha konieczna przy wypełnianiu tak delikatnej misji, jak przekonanie kilkunastoletniej dziewczyny do zostania Matką Syna Bożego. O niezwykłości owej misji świadczy m.in. zapewnienie Adama Opatowczyka, który w Pośle zbawienia autorytatywnie stwierdził, iż nigdy wcześniej Stwórca nie wyprawiał w taki sposób swego legata - zazwyczaj o decyzji powiadamiał posła za pośrednictwem innych aniołów, tym razem jednak sam przekazał instrukcje ${ }^{30}$.

Dziesięć następnych wersów Obodziński poświęcił atrybutom poselskim. Wyliczył stosowane w różnych narodach insygnia pozwalające rozpoznać wysłannika:

\author{
Ale patrzmy, jeśli ma swe poselskie znaki, \\ Jeśli zwyc[z]ajnym posłom w splendorze jednaki. \\ Zwyczajna u postronnych narodów to była, \\ Że znakiem pewnym posła cudzego znaczyła: \\ Chaldejczykowie ogień na tarczy miewali, \\ A Babilończykowie kolumn zażywali. \\ Rzymianie Orła mieli, znak posła swojego, \\ Persowie zażywali łuka bawolego. \\ Ma i ten zaczny poseł złotonitną szatę, \\ Jasno-biało, bo biało przynosi prywatę ${ }^{31}$.
}

Charakterystyczne, że autor Poważnej legacyi, gdy przyszło mu już opisać Gabriela, skoncentrował się na jego stroju, a nie na innych artefaktach. Problem ubioru, w jakim anioł stanął przed Maryją, zajmował wielu twórców, lecz nie w takim kontekście, jak to się stało w Poważnej legacyi. Najciekawiej temat ów ujął wspomniany już Andrzej Karp. Przywołując w jednym ze swych kazań rozważania sławnych teologów, starał się wyjaśnić, czy anioł miał na sobie ubogie czy piękne szaty $^{32}$. Obodziński odniósł się natomiast do „gry kolorów”, uznając, że biała szata przetykana złotymi nićmi jest oznaka godności poselskiej. Zreszta problem ubioru legata podejmowali też pisarze, spod piór których wychodziły opracowania dotyczace sztuki poselskiej. Nie był to przy tym problem błahy, albowiem sądzono, iż prezencja podwładnego świadczy także o jego $\mathrm{panu}^{33}$. W pierwszym polskim podręczniku dyplomacji, czyli w dziele De legato legationeque liber Krzysztof Warszewicki zauważył m.in., że zbyt wyszukany strój posła to znak próżności, niechlujność zaś dowodzi skąpstwa ${ }^{34}$. Obodziński - powtórzmy - nie zajął się kwestią estetyczną, ale po prostu uznał, iż ubiór posła jest istotnym wyróżnikiem. Przyodziany w biało-

mu misji (warto przypomnieć, że nie wszystkich posłańców tak określano, rozróżniając wśród nich: gońców, posłów, posłów wielkich oraz komisarzy).

A. O p a t o w c zy k, Poset zbawienia, Panien zakonnych klasztoru świętego Andrzeja [...]. Kraków 1644, s. 22.

31 Obodziński, op. cit., k. $\mathrm{B}_{2} \mathrm{v}$.

32 A. Karp, Macierzyństwo Boskie szlakujace [...]. W: Lutnia wdzięczno-brzmiaca [...], s. 80-81.

33 Zob. E. Goffman, Człowiek $w$ teatrze życia codziennego. Przeł. H. Datner-Ś piewak, P. Ś piewak. Oprac., wstęp J. Szacki. Warszawa 2008, s. 133.

34 K. Warszewicki, O pośle i poselstwach. Oprac. J. Ży cki. Przedm. I. Matuszews ki. Warszawa 1935, s. 128-131. Zob. też M. Barłow s ka, Jerzy Ossoliński. Orator polskiego baroku. Katowice 2000, s. 42. 
-złotą szatę Gabriel „postrachu przy sobie nie nosi [...]” i dzięki temu doskonale sprawuje funkcję posła dostarczającego dobre wieści ${ }^{35}$.

Przytoczone fragmenty Posła niebieskiego oraz Poważnej legacyi nie sa jedynymi, w których Dębołęcki i Obodziński wspominają o niebiańskiej świcie. W końcowej partii omawianych dzieł ukazano anioły i świętych, którzy radują się z Wniebowzięcia Matki Bożej. Obrazy te budują swoistą klamrę kompozycyjną: najpierw autorzy przedstawili otoczenie Stwórcy, a później dwór Maryi (w obu przypadkach rozumiane i jako przestrzeń, i jako określona społeczność). Jednak tylko pierwszy autor zdecydował się na wyrażenie zachwytu poetyckiego, dzięki któremu ujrzał tron Stwórcy - narrator w dziele Dębołęckiego zobaczył Boga Ojca i Jego otoczenie za sprawą ekstazy twórczej. Ten rzadki w naszej literaturze sposób na wyjaśnienie wiedzy o zaświatach (w Pośle pojawił się on zapewne pod wpływem De partu Virgi$n i s^{36}$ ) uzasadnia występowanie znacznie bardziej popularnego tematu w piśmiennictwie staropolskim, czyli dworu niebieskiego. Przedstawianie tej metafizycznej abstrakcji na wzór rzeczywistości materialnej bliskiej schematom myślowym przeciętnego mieszkańca XVII-wiecznej Rzeczpospolitej wydaje się szczególnie ważne w utworach, których nie zalicza się do wybitnych: odzwierciedlają one świat wyobraźni nie tylko pisarzy, ale również przeciętnych czytelników. W przypadku dzieł Andrzeja Dębołęckiego i Aleksandra Obodzińskiego sa jeszcze natomiast kolejnym dowodem znaczenia, jakie w kulturze europejskiej miała epopeja De partu Virginis Sannazara.

Abstract

DARIUSZ DYBEK University of Wrocław ORCID: 0000-0002-5036-3999

\section{GOD'S ESTATE (AND ARCHANGEL GABRIEL) IN ANDRZEJ DĘBOŁECKI'S "POSEL NIEBIESKI" ("HEAVENLY ENVOY") AND IN ALEKSANDER OBODZIŃSKI'S "POWAŻNA LEGACYJA” (“THE IMPORTANT MISSION”)}

The paper refers to the epic poems by the Polish baroque writers who took up religious themes, namely to Andrzej Dębołęcki's Poseł niebieski, to jest Archanioła Gabryjela nowiny z nieba do Panny czystej Maryjej o wcieleniu Syna Bożego w jej żywot sprawujacego (Message of Heavenly Envoy Archangel Gabriel to Holy Mary, Pure Virgin, about the Incarnation of the Son of God into Her Life) (Torun 1633) and Aleksander Obodziński's Poważna legacyja w Konsystorzu Trójce Przenaświętszej (The Important Mission in the Consistory of the Holy Trinity) (Kraków [1640]). The authors, referring to Jacopo Sannazaro's epopee De partu Virginis, in their works presented an independent (though recalling tradition) evangelical motive of transferring Mary the message by Archangel Gabriel that she is going to be God's Mother. It must also be mentioned that Obodziński in many places plagiarised Debołęcki. Both of the writers focused on describing God's estate, and first and foremost on the appearance of Archangel Gabriel and his diplomatic skills which he showed as the envoy sent with the Annunciation.

Warto jeszcze raz przypomnieć, iż pierwotne znaczenie hebrajskiego słowa „mal'ak” i jego greckiego odpowiednika „aggelos” to 'posłaniec'. Niemal wszystkie dzieła z dziedziny angelologii podkreślają, że wyraz „anioł” wiązał się z funkcją, a nie osobą.

Zob. Czaradzki, op. cit., s. 91 . 